\title{
Aplikasi Pupuk Granular Organik Berbahan Limbah Sawit dan Rhizobium terhadap Pertumbuhan dan Hasil Kacang Tanah
}

\author{
(Application of Organic Granul Fertilizer Based on Palm Waste and Rhizobium on Growth and Yield of Peanuts)
}

\author{
Edi Susilo $^{1 *}$
}

${ }^{1}$ Program Studi Agroteknologi, Fakultas Pertanian, Universitas Ratu Samban, Bengkulu Utara

Jl. Jendral Sudirman No. 87 Arga Makmur Kabupaten Bengkulu Utara Propinsi Bengkulu 38611. HP. 085235229104

*Email korespondensi : susilo_agr@yahoo.com

Diterima 25 Februari 2019/Disetujui 01 Maret 2019

\begin{abstract}
Peanuts are the most important agricultural commodities after soybeans which have a strategic role in national food as a source of protein and vegetable oil, so that it has the potential to be developed because it has good economic value and has a large domestic market opportunity. This study aims to obtain information on the application of organic granular fertilizers and rhizobium and their interactions with the growth and yield of peanuts. The research was carried out at the experimental land of the Faculty of Agriculture at the University of Ratu Samban Arga Makmur Bengkulu Utara from June to September 2018. The research method used a two-factor randomized block design with 3 replications. The first factor was the treatment of organic granular fertilizer with six levels, control (G0), organic granular fertilizer $25 \mathrm{~g}_{\text {plant }}^{-1}$ (G1), organic granular fertilizer $50 \mathrm{~g}_{\text {plant }^{-1}}$ (G2), organic granular fertilizer $100 \mathrm{~g} \mathrm{plant}^{-1}$ (G3), organic granular fertilizer 150 $\mathrm{g}$ plant ${ }^{-1}$ (G4), organic granular fertilizer $200 \mathrm{~g}_{\text {plant }}^{-1}(\mathrm{G} 5)$. The second factor is the treatment of Rhizobium, consisting of two levels, namely control (RO) and rhizobium (R1). The results showed that the treatment of organic granular fertilizer had a significant effect on seed weight per plant and treatments of $100 \mathrm{~g} \mathrm{plant}^{-1}$ and $150 \mathrm{~g}_{\text {plant }}^{-1}$ produced the highest seed weight of tan-1 $9.38 \mathrm{~g}$ and $9.32 \mathrm{~g}$, respectively. Rhizobium treatment significantly affected plant height and number of branches 7 week after planting. Rhizobium treatment produced the highest plant height of $36.11 \mathrm{~cm}$ and more branches of 5.56 stems. There is no interaction between granular organic fertilizer and rhizobium.
\end{abstract}

Keywords: organic, fertilizer, peanut, rhizobium.

\section{ABSTRAK}

Kacang tanah (Arachis hypogaea L) merupakan komoditas pertanian terpenting setelah kedelai yang memiliki peran strategis pangan nasional sebagai sumber protein dan minyak nabati, sehingga berpotensi untuk dikembangkan karena memiliki nilai ekonomi yang cukup baik dan mempunyai peluang pasar dalam negeri cukup besar. Penelitian ini bertujuan memperoleh informasi aplikasi pupuk granular organik dan rhizobium serta interkasinya terhadap pertumbuhan dan hasil kacang tanah. Penelitian ini dilaksanakan di Kebun Percobaan Fakultas Pertanian Universitas Ratu Samban Arga Makmur Bengkulu Utara pada bulan Juni sampai September 2018. Metode penelitian menggunakan Rancangan Acak Kelompok dua faktor dengan 3 ulangan. Faktor pertama adalah perlakuan pupuk granular organik dengan enam taraf yaitu kontrol (G0), pupuk granular organik $25 \mathrm{~g} \mathrm{tan}^{-1}(\mathrm{Gl})$, pupuk granular organik $50 \mathrm{~g} \mathrm{tan}^{-1}(\mathrm{G} 2)$, pupuk granular organik $100 \mathrm{~g}$ tan $^{-1}(\mathrm{G} 3)$, pupuk granular organik $150 \mathrm{~g} \mathrm{tan}^{-1}(\mathrm{G} 4)$, pupuk granular organik $200 \mathrm{~g} \mathrm{tan}^{-1}$ (G5). Faktor kedua perlakuan rhizobium, terdiri atas 2 taraf yaitu kontrol (RO) dan rhizobium (R1). Hasil penelitian menunjukkan bahwa perlakuan pupuk granular organik berpengaruh nyata terhadap bobot biji per tanaman dan perlakuan $100 \mathrm{~g} \mathrm{tan}^{-1}$ dan $150 \mathrm{~g} \mathrm{tan}^{-1}$ menghasilkan bobot biji tan $^{-1}$ tertinggi masing-masing $9.38 \mathrm{~g}$ dan $9.32 \mathrm{~g}$. Perlakuan rhizobium berpengaruh nyata terhadap tinggi tanaman dan jumlah cabang 7 minggu setelah tanam (MST). Perlakuan rhizobium menghasilkan tinggi tanaman tertinggi sebesar $36.11 \mathrm{~cm}$ dan jumlah cabang lebih banyak yaitu 5.56 batang. Tidak terdapat interaksi antara pupuk organik granular dengan rhizobium.

Kata kunci: kacang tanah, organik, pupuk, rhizobium

\section{PENDAHULUAN}

Kacang tanah merupakan komoditas pertanian terpenting setelah kedelai yang memiliki peran strategis pangan nasional sebagai sumber protein dan minyak nabati.
Kacang tanah termasuk tanaman kacang-kacangan yang berpotensi untuk dikembangkan karena memiliki nilai ekonomi yang cukup baik dan mempunyai peluang pasar dalam negeri cukup besar (Marzuki, 2007). Selanjutnya Marzuki (2007) juga menyatakan bahwa kacang tanah 
mengandung gizi yakni protein $25-30 \%$, lemak $40-50 \%$, karbohidrat $12 \%$ serta vitamin B1 dan menempatkan kacang tanah dalam hal pemenuhan gizi setelah tanaman kedelai. Kacang tanah dimanfaatkan sebagai bahan pangan konsumsi langsung atau campuran makanan seperti roti, bumbu dapur, bahan baku industri, dan pakan ternak, sehingga kebutuhan kacang tanah terus meningkat setiap tahunnya sejalan dengan peningkatan jumlah penduduk (Balitkabi 2008).

Kebutuhan dan permintaan kacang tanah semakin meningkat dari tahun ke tahun namun tidak diikuti dengan produksinya. Menurut Ditjen Tanaman Pangan (2012) kebutuhan kacang tanah Indonesia terus meningkat rata-rata 900,000 ton dengan produksi rata-rata 783,110 ton setiap tahun, sehingga produksi nasional hanya mampu memenuhi sekitar $87.01 \%$ dari kebutuhan kacang tanah. Pada tahun 2011, produksi dalam negeri sebesar 691,289 ton yang diperoleh dari luas panen 539,459 ha. Rendahnya produksi kacang tanah tersebut disebabkan oleh rendahnya produktivitas yang hanya mencapai 1.28 ton ha ${ }^{-1}$. Tingkat produktivitas yang dicapai ini baru setengah dari potensi hasil apabila dibandingkan dengan Amerika, China, dan Argentina yang sudah mencapai lebih dari 2.0 ton $\mathrm{ha}^{-1}$ (Adisarwanto, 2000).

Permasalahan yang dihadapi dalam meningkatkan produksi kacang tanah nasional disebabkan oleh beberapa hal diantaranya: a) Penerapan teknologi belum dilakukan dengan baik, sehingga produktivitas belum optimal misalnya, pengolahan lahan kurang optimal sehingga drainase buruk dan struktur tanah menjadi padat, pemeliharaan tanaman kurang optimal sehingga serangan organisme pengganggu tanaman (OPT) tinggi b) Penggunaan benih bermutu masih rendah, c) Penggunaan pupuk hayati dan organik masih rendah. Peningkatan produksi kacang tanah dapat dicapai melalui beberapa strategi, diantaranya: a) Peningkatan produktivitas, yang dilakukan adalah menerapkan teknologi produksi yang tepat guna, pengembangan dan penerapan teknologi budidaya terbaru, dan perlindungan tanaman dari OPT. b) Perluasan lahan budidaya dan optimalisasi lahan dilakukan dengan membuka lahan baru, mengoptimalkan lahan dengan memanfaatkan lahan marjinal dan lahan pertanian lainnya (Dirjen Tanaman Pangan 2012).

Tanah adalah salah satu faktor produksi yang sangat penting bagi usaha pertanian. Kegagalan usaha pertanian biasa disebabkan karena rendahnya kualitas sumber daya tanah yang dijadikan sebagai media tumbuh tanaman. Oleh karena itu penggunaan pupuk dalam rangka meningkatkan hara tanah adalah merupakan salah satu cara yang dilakukan, mengingat pemanfaatan lahan terus-menerus tanpa diikuti suplai hara dari luar, sulit memperoleh produksi yang maksimal mengingat kemampuan tanah sangat terbatas (Sutedjo, 1995). Upaya mengatasi permasalahan pada tanah, salah satunya dengan pemupukan. Pupuk merupakan suatu bahan yang diberikan pada tanaman baik secara langsung maupun tidak langsung untuk mendorong pertumbuhan tanaman, meningkatkan produksi atau memperbaiki kualitas maupun kuantitas dari tanaman tersebut (Leiwakabessy dan Sutandi, 2004).

Penggunaan pupuk anorganik secara terus-menerus tanpa diikuti pemberian pupuk organik dapat menurunkan kualitas fisik, kimia, dan bilogi tanah (Padmanabha et al., 2014). Menurut Bending et al., (2004), pemberian pupuk anorganik pada dosis tinggi dapat menurunkan populasi dan keragaman mikroba, sehingga mikroba yang berperan dalam mineralisasi senyawa organik akan berkurang populasinya. Diperlukan pupuk organik atau kompos sebagai bahan pemeliharaan tanah pertanian. Pupuk organik mengandung hara yang lengkap meskipun kadarnya tidak sebanyak pupuk buatan. Kari et al. (2000) penambahan bahan organik dapat meningkatkan efisiensi penyerapan unsur phosfor $(\mathrm{P})$, yang dapat meningkatkan agregasi tanah sehingga tanah menjadi lebih gembur dan sangat menguntungkan untuk pertumbuhan ginofor kacang tanah. Pemberian pupuk organik mampu meningkatkan kesuburan tanah, selain itu juga memperbaiki struktur tanah dengan pemantapan agregat tanah, aerasi, dan daya menahan air, serta kapasitas tukar kation. Struktur tanah yang baik menjadikan perakaran berkembang dengan baik sehingga semakin luas bidang serapan terhadap unsur hara. Penggunaan pupuk organik dapat dianggap sebagai pupuk yang lengkap, karena bisa meningkatkan aktivitas mikroorganisme di dalam tanah. Bahan organik yang diberikan ke dalam tanah selain menambah unsur hara bagi tanaman juga menjadi makanan organisme di dalam tanah. Oleh sebab itu, pemberian pupuk organik dapat meningkatkan aktivitas bakteri rhizobium sehingga dapat dengan baik menginfeksi akar tanaman kacang tanah dan dapat meningkatkan nitrogen yang dibutuhkan oleh tanaman kacang tanah.

Peningkatan produksi dapat juga diupayakan dengan memperbaiki tanah secara kultur teknis, seperti perawatan tanaman, pemupukan yang tepat dan sistem drainase. Pemanfaatan rhizobium sebagai inokulan dapat meningkatkan ketersediaan nitrogen bagi tanaman, yang dapat mendukung peningkatan produktivitas tanaman kacang-kacangan (Saraswati dan Sumarno, 2008). Pemberian inokulum rhizobium dengan pupuk organik dimaksudkan agar memberikan dampak positif untuk produksi kacang tanah dengan cara perbaikan sifat fisik, kimia dam biologi tanah.

Penelitian ini bertujuan 1). Memperoleh informasi aplikasi pupuk granular organik terhadap pertumbuhan dan hasil kacang tanah, 2). Memperoleh informasi aplikasi rhizobium terhadap pertumbuhan dan hasil kacang tanah, 3). Mendapatkan informasi interaksi antara pupuk granular organik dan rhizobium terhadap pertumbuhan dan hasil kacang tanah.

\section{BAHAN DAN METODE}

Penelitian ini dilaksanakan di Kebun Percobaan Fakultas Pertanian Universitas Ratu Samban Arga Makmur Bengkulu Utara pada bulan Juni sampai September 2018. Bahan yang digunakan adalah benih kacang tanah varietas Talam 1, polybag ukuran $10 \mathrm{~kg}$ media tanah, tanah top soil, 
rhizobium, dan pupuk organik granular berbahan limbah sawit. Alat yang digunakan adalah timbangan digital, timbangan manual, penggaris, ember, cangkul, sekop, gembor, plastik, label, nampan, dan alat tulis. Metode penelitian menggunakan Rancangan Acak Kelompok (RAK) dua faktor dengan 3 ulangan. Faktor pertama adalah perlakuan pupuk organik granular dengan enam taraf yaitu kontrol (G0), pupuk organik granular $25 \mathrm{~g} \mathrm{tan}^{-1}(\mathrm{G} 1)$, pupuk organik granular $50 \mathrm{~g} \mathrm{tan}^{-1}(\mathrm{G} 2)$, pupuk organik granular 100 $\mathrm{g} \mathrm{\operatorname {tan } ^ { - 1 }}(\mathrm{G} 3)$, pupuk organik granular $150 \mathrm{~g} \mathrm{tan}^{-1}(\mathrm{G} 4)$, pupuk organik granular $200 \mathrm{~g} \mathrm{tan}^{-1}$ (G5). Faktor kedua perlakuan rhizobium, terdiri atas 2 taraf yaitu kontrol (R0) dan rhizobium (R1).

Kegiatan awal yang dilakukan pada penelitian ini adalah pengumpulan bahan penelitian berupa pupuk organik granular. Pupuk organik granular diperoleh dari PT Bio Nusantara Teknologi Kabupaten Bengkulu Tengah Propinsi Bengkulu. Pupuk granular organik ditimbang sesuai perlakuan. Rizhobium diperoleh dari kios pertanian Dramaga Bogor dan benih kacang tanah diperoleh dari Balai Penelitian Kacang-kacangan dan Umbi-umbian (Balitkabi) Malang Jawa Timur.

Media topsoil disiapkan sebanyak 1,080 kg. Media ini dibagi ke dalam 108 polybag, masing-masing bagian seberat $10 \mathrm{~kg}_{\text {polybag }}{ }^{-1}$. Tanah topsoil dicampur secara komposit dan dimasukkan dalam polybag. Media tanam dalam polybag ini didiamkan selama sepuluh hari bertujuan untuk mendapatkan media yang baik.

Benih kacang tanah dikupas dari polongnya selanjutnya dipisahkan benih yang akan diperlakukan dengan rhizobium dan tanpa rhizobium. Untuk benih dengan perlakuan rhizobium dicampur dengan rhizobium yang sebelumnya telah ditambahkan air sedikit yang telah berbentuk pasta. Pencampuran dilakukan secara merata antara benih kacang tanah dengan rhizobium, selanjutnya dikering anginkan sebelum dilakukan penanaman. Untuk benih tanpa perlakuan rhizobium berarti tanpa ada perlakuan yang diterapkan pada benih tersebut.

Penanaman benih kacang tanah dilakukan sesaat pencampuran benih dan rhizobium. Media tanam di polybag diberi lubang tanam dengan kedalaman $2 \mathrm{~cm}$ sebanyak 3 lubang tanam. Lubang tanam diberi Karbofuran sebanyak 10 butir untuk mencegah hama tanah. Lubang tanam yang telah dibuat, ditanam benih kacang tanah sebanyak 1 benih, selanjutnya lubang tanam ditutup dengan tanah lapisan atas. Setiap polybag terdapat 3 calon tanaman kacang tanah. Penjarangan dilakukan pada umur 2 minggu setelah tanam dengan menyisakan 2 tanaman per polybag yang pertumbuhannya terbaik.

Pemeliharaan tanaman meliputi penyiraman, pemupukan, pengendalian hama penyakit dan gulma. Kegiatan penyiraman dilakukan pada sore hari menggunakan alat berupa gembor. Pengendalian gulma dilakukan bila gulma telah tumbuh di media polybag dengan cara mencabut secara manual menggunakan tangan. Pengendalian hama dan penyakit tanaman dilakukan dengan metode pencegahan untuk mendapatkan tanaman yang selalu terjaga dan terlindungi dari serangan hama penyakit tanaman. Pengendalian atau pencegahan hama tanaman kacang tanah dilakukan setiap sepuluh hari sekali menggunakan insektisida berbahan aktif Profenofos.

Kegiatan aplikasi pupuk dilakukan dengan metode penaburan pupuk granular organik pada media tanah di pangkal batang tanaman kacang tanah $(5 \mathrm{~cm})$ sesuai perlakuan yang diterapkan. Kegiatan pemberian pupuk ini dilakukan seminggu setelah tanam dan sekali selama periode hidup. Untuk pupuk anorganik lainnya berupa Urea, TSP dan KCl. Pupuk Urea dosis $100 \mathrm{~kg} \mathrm{ha}^{-1}$ diaplikasikan 2 kali pada saat tanam dan pada umur 3 minggu setelah tanam. Pupuk TSP $150 \mathrm{~kg} \mathrm{ha}{ }^{-1}$ dan $\mathrm{KCl}$ dosis $150 \mathrm{~kg} \mathrm{ha}{ }^{-1}$ diaplikasikan saat tanam.

Pemanenan kacang tanah dilakukan apabila umur telah mencapai 95 hari setelah tanam (HST) yang mempunyai ciri-ciri daun kecoklatan dan telah gugur. Pemanenan kacang tanah dilakukan dengan cara mencabut batang kacang tanah, selanjutnya polong dibersihkan dari tanah dan melepas polong dari tangkainya. Polong yang sudah lepas dari tangkainya selanjutnya dijemur sampai kering. Polong yang telah kering dikupas dan mendapatkan biji kacang tanah yang telah bersih. Selanjutnya biji kacang tanah ditimbang dan dicatat sesuai label perlakuan.

Pengamatan tanaman kacang tanah dilakukan terhadap variabel tinggi tanaman, jumlah daun, jumlah cabang, dan bobot biji per tanaman. Data hasil pengamatan dianalisis dengan sidik ragam untuk mengetahui pengaruh perlakuan yang dicobakan dan apabila dari hasil analisis berpengaruh nyata maka dilanjutkan dengan uji DMRT pada taraf kepercayaan 95\% (Mattjik dan Sumertajaya, 2006).

\section{HASIL DAN PEMBAHASAN}

Rekapitulasi sidik ragam pertumbuhan kacang tanah dapat dilihat pada Tabel 1. Hasil analisis ragam menunjukkan bahwa terdapat pengaruh nyata perlakuan pupuk granular organik terhadap variabel bobot biji per tanaman, namun tidak berbeda nyata pada variabel lainnya. Perlakuan rhizobium menunjukkan berpengaruh nyata terhadap variabel tinggi tanaman dan jumlah cabang 7 MST, namun tidak berbeda nyata pada variabel lainnya. Pada interaksi antara pupuk granular organik dengan rhizobium menunjukkan tidak berpengaruh nyata pada semua variabel.

Pada variabel tinggi tanaman menunjukkan bahwa perlakuan pupuk granular organik tidak berpengaruh nyata terhadap variabel tinggi tanaman umur 5 MST dan 7 MST. Terdapat kecenderungan bahwa pupuk granular organik 150 g $\tan ^{-1}$ menghasilkan tinggi tanaman tertinggi, terutama umur 7 MST. Hal ini menunjukkan bahwa terdapat perlakuan granular organik yang cenderung menghasilkan tinggi tanaman terbaik yaitu dosis $150 \mathrm{~g} \mathrm{tan}^{-1}$. Pada perlakuan rhizobium menunjukkan tidak berpengaruh nyata terhadap tinggi tanaman umur 5 MST namun berbeda nyata pada umur 7 MST. Perlakuan rhizobium ternyata menghasilkan tinggi tanaman yang tertinggi $(36.11 \mathrm{~cm})$ jika dibandingkan dengan tanpa rhizobium $(32.58 \mathrm{~cm})$. Hal ini menunjukkan bahwa aplikasi rhizobium pada tanaman kacang tanah ternyata mampu meningkatkan variabel pertumbuhan tanaman khususnya tinggi tanaman umur 7 MST. 
Tabel 1. Rekapitulasi aplikasi pupuk granular organik dan rhizobium terhadap pertumbuhan dan hasil kacang tanah

\begin{tabular}{clcccc}
\hline No & Variabel pengamatan & $\begin{array}{c}\text { Pupuk granular } \\
\text { organik }(\mathrm{G})\end{array}$ & $\begin{array}{c}\text { Rhizobium } \\
(\mathrm{R})\end{array}$ & $\begin{array}{c}\text { Interaksi } \\
(\mathrm{G} \times \mathrm{R})\end{array}$ & KK $(\%)$ \\
\hline 1 & Tinggi tanaman 5 MST & $1.18 \mathrm{tn}$ & $0.37 \mathrm{tn}$ & $2.18 \mathrm{tn}$ & 18.62 \\
2 & Tinggi tanaman 7 MST & $1.78 \mathrm{tn}$ & $6.73 *$ & $1.94 \mathrm{tn}$ & 11.88 \\
3 & Jumlah daun 5 MST & $0.64 \mathrm{tn}$ & $1.29 \mathrm{tn}$ & $0.47 \mathrm{tn}$ & 20.86 \\
4 & Jumlah daun 7 MST & $0.96 \mathrm{tn}$ & $2.90 \mathrm{tn}$ & $0.71 \mathrm{tn}$ & 13.95 \\
5 & Jumlah cabang 5 MST & $1.46 \mathrm{tn}$ & $0.68 \mathrm{tn}$ & $1.64 \mathrm{tn}$ & 18.71 \\
6 & Jumlah cabang 7 MST & $0.56 \mathrm{tn}$ & $4.52 *$ & $1.30 \mathrm{tn}$ & 14.08 \\
7 & Bobot biji tan $^{-1}$ & $4.53 * *$ & $0.07 \mathrm{tn}$ & $0.60 \mathrm{tn}$ & 24.04 \\
\hline
\end{tabular}

$\begin{array}{ll}\text { Keterangan : } & *=\text { berbeda nyata } \\ & * *=\text { berbeda sangat nyata } \\ & \text { tn }=\text { tidak berbeda nyata }\end{array}$

Tabel 2. Rataan tinggi tanaman kacang tanah akibat aplikasi pupuk granular organik dan rhizobium

\begin{tabular}{|c|c|c|}
\hline \multirow{2}{*}{ Perlakuan } & \multicolumn{2}{|c|}{ Tinggi $(\mathrm{cm})$} \\
\hline & $5 \mathrm{MST}$ & $7 \mathrm{MST}$ \\
\hline \multicolumn{3}{|c|}{ Pupuk granular organik: } \\
\hline $0 \mathrm{~g} \mathrm{tan}^{-1}(\mathrm{G} 0)$ & $16.25 \mathrm{a}$ & $34.92 \mathrm{a}$ \\
\hline $25 \mathrm{gtan}^{-1}(\mathrm{G} 1)$ & $19.17 \mathrm{a}$ & $34.00 \mathrm{a}$ \\
\hline $50 \mathrm{~g} \mathrm{tan}^{-1}(\mathrm{G} 2)$ & $15.83 \mathrm{a}$ & $30.25 \mathrm{a}$ \\
\hline $100 \mathrm{~g} \mathrm{tan}^{-1}(\mathrm{G} 3)$ & $17.33 \mathrm{a}$ & $34.67 \mathrm{a}$ \\
\hline $150 \mathrm{~g} \mathrm{tan}^{-1}(\mathrm{G} 4)$ & $18.75 \mathrm{a}$ & $36.83 \mathrm{a}$ \\
\hline $200 \mathrm{~g} \mathrm{tan}^{-1}(\mathrm{G} 5)$ & $19.00 \mathrm{a}$ & $35.42 \mathrm{a}$ \\
\hline \multicolumn{3}{|l|}{ Rhizobium : } \\
\hline Kontrol (R0) & $17.39 \mathrm{a}$ & $32.58 \mathrm{~b}$ \\
\hline Rhizobium (R1) & $18.06 \mathrm{a}$ & $36.11 \mathrm{a}$ \\
\hline
\end{tabular}

Tabel 3. Rataan jumlah daun kacang tanah akibat aplikasi pupuk granular organik dan rhizobium

\begin{tabular}{lcc}
\hline Perlakuan & \multicolumn{2}{c}{ Jumlah daun (helai) } \\
\cline { 2 - 3 } Pupuk granular organik : & $5 \mathrm{MST}$ & MST \\
$0 \mathrm{~g} \mathrm{tan}^{-1}(\mathrm{G} 0)$ & $21.42 \mathrm{a}$ & $31.25 \mathrm{a}$ \\
$25 \mathrm{~g} \mathrm{tan}^{-1}(\mathrm{G} 1)$ & $18.50 \mathrm{a}$ & $32.00 \mathrm{a}$ \\
$50 \mathrm{~g} \mathrm{tan}^{-1}(\mathrm{G} 2)$ & $17.75 \mathrm{a}$ & $29.08 \mathrm{a}$ \\
$100 \mathrm{~g} \mathrm{tan}^{-1}(\mathrm{G} 3)$ & $19.25 \mathrm{a}$ & $33.83 \mathrm{a}$ \\
$150 \mathrm{~g} \mathrm{tan}^{-1}(\mathrm{G} 4)$ & $18.25 \mathrm{a}$ & $33.83 \mathrm{a}$ \\
$200 \mathrm{~g} \mathrm{tan}^{-1}(\mathrm{G} 5)$ & $18.67 \mathrm{a}$ & $31.75 \mathrm{a}$ \\
\hline Rhizobium : & & $30.69 \mathrm{a}$ \\
Kontrol (R0) & $18.22 \mathrm{a}$ & $33.22 \mathrm{a}$ \\
\hline Rhizobium (R1) & $19.72 \mathrm{a}$ & \\
\hline
\end{tabular}

Keterangan : angka-angka yang diikuti huruf yang sama pada kolom yang sama tidak berbeda nyata pada uji DMRT taraf 5\%.

Hal ini juga sesuai dengan hasil penelitian yang dilakukan Fitriana et al., (2015) yang menyatakan pemberian inokulum rhizobium $10 \mathrm{~g} / \mathrm{kg}$ benih dan jenis pupuk kandang ayam memberikan hasil jumlah polong lebih tinggi dibandingkan dengan pemberian inokulum rhizobium $0 \mathrm{~g} / \mathrm{kg}$ benih dan tanpa pupuk kandang. Kemampuan Rhizobium dalam menambat nitrogen dari udara dipengaruhi oleh besarnya bintil akar dan jumlah bintil akar, semakin besar bintil akar atau semakin banyak bintil akar yang terbentuk, semakin besar nitrogen yang ditambat (Arimurti, 2000). Pertumbuhan bakteri rhizobium dipengaruhi oleh ketersediaan unsur hara pada lingkungan perakaran dan tentunya akan berpengaruh pada fiksasi $\mathrm{N}_{2}$. Kelebihan atau kekurangan unsur hara akan berdampak buruk terhadap pertumbuhan rhizobium dan fiksasi $\mathrm{N}_{2}$. Hasil penelitian Nuha, dkk (2014) bahwa penggunaan legin dan kompos memberikan pengaruh nyata pada bintil akar efektif karena lahan tanpa kompos dan lahan yang diberi kompos dapat meningkatkan bakteri rhizobium di dalam tanah dan kompos berfungsi sebagai sumber nutrisi bagi tanaman serta berperan dalam menyediakan kondisi lingkungan yang sesuai dengan kehidupan bakteri rhizobium. 
Tabel 4. Rataan jumlah cabang kacang tanah akibat aplikasi pupuk granular organik dan rhizobium

\begin{tabular}{|c|c|c|}
\hline \multirow{2}{*}{ Perlakuan } & \multicolumn{2}{|c|}{ Jumlah cabang (batang) } \\
\hline & $5 \mathrm{MST}$ & $7 \mathrm{MST}$ \\
\hline \multicolumn{3}{|l|}{ Pupuk granular organik : } \\
\hline $0 \mathrm{~g} \mathrm{tan}^{-1}(\mathrm{G} 0)$ & $4.67 \mathrm{a}$ & $5.33 \mathrm{a}$ \\
\hline $25 \mathrm{~g} \mathrm{tan}^{-1}(\mathrm{G} 1)$ & $4.33 \mathrm{a}$ & $5.42 \mathrm{a}$ \\
\hline $50 \mathrm{~g} \mathrm{tan}^{-1}(\mathrm{G} 2)$ & $3.67 \mathrm{a}$ & $4.83 \mathrm{a}$ \\
\hline $100 \mathrm{~g} \mathrm{tan}^{-1}(\mathrm{G} 3)$ & $4.08 \mathrm{a}$ & $5.42 \mathrm{a}$ \\
\hline $150 \mathrm{~g} \mathrm{tan}^{-1}(\mathrm{G} 4)$ & $4.33 \mathrm{a}$ & $5.42 \mathrm{a}$ \\
\hline $200 \mathrm{~g} \mathrm{tan}^{-1}(\mathrm{G} 5)$ & $4.75 \mathrm{a}$ & $5.33 \mathrm{a}$ \\
\hline \multicolumn{3}{|l|}{ Rhizobium : } \\
\hline Kontrol (R0) & $4.19 \mathrm{a}$ & $5.03 \mathrm{~b}$ \\
\hline Rhizobium (R1) & $4.42 \mathrm{a}$ & $5.56 \mathrm{a}$ \\
\hline
\end{tabular}

Keterangan : angka-angka yang diikuti huruf yang sama pada kolom yang sama tidak berbeda nyata pada uji DMRT taraf 5\%.

Tabel 5. Rataan bobot biji tanaman kacang tanah akibat aplikasi pupuk granular organik dan rhizobium

\begin{tabular}{lc}
\hline \multicolumn{1}{c}{ Perlakuan } & Bobot biji $(\mathrm{g})$ \\
\hline Pupuk granular organik : & $3.83 \mathrm{c}$ \\
$0 \mathrm{~g} \mathrm{tan}^{-1}(\mathrm{G} 0)$ & $5.80 \mathrm{bc}$ \\
$25 \mathrm{~g} \mathrm{tan}^{-1}(\mathrm{G} 1)$ & $8.39 \mathrm{ab}$ \\
$50 \mathrm{~g} \mathrm{tan}^{-1}(\mathrm{G} 2)$ & $9.32 \mathrm{a}$ \\
$100 \mathrm{~g} \mathrm{tan}^{-1}(\mathrm{G} 3)$ & $9.38 \mathrm{a}$ \\
$150 \mathrm{~g} \mathrm{tan}^{-1}(\mathrm{G} 4)$ & $8.27 \mathrm{ab}$ \\
$200 \mathrm{~g} \mathrm{tan}^{-1}(\mathrm{G} 5)$ & \\
\hline Rhizobium : & $7.61 \mathrm{a}$ \\
Kontrol (R0) & $7.38 \mathrm{a}$ \\
\hline Rhizobium (R1) & \\
\hline Keterangan : angka-angka yang diikuti huruf yang sama pada kolom yang sama tidak berbeda nyata pada uji DMRT taraf 5\%.
\end{tabular}

Pada variabel jumlah daun menunjukkan bahwa perlakuan pupuk granular organik tidak berpengaruh nyata terhadap variabel jumlah daun umur 5 MST maupun 7 MST. Terdapat kecenderungan bahwa perlakuan pupuk granular organik $100 \mathrm{~g} \tan ^{-1}$ maupun $150 \mathrm{~g} \tan ^{-1}$ menghasilkan jumlah daun lebih banyak jika dibandingkan dengan perlakuan lainnya, terutama umur 7 MST. Hal ini menunjukkan bahwa terdapat dosis yang cenderung meningkatkan jumlah daun yaitu dosis $100 \mathrm{~g} \mathrm{tan}^{-1}$ maupun $150 \mathrm{~g} \tan ^{-1}$. Pada perlakuan rhizobium ternyata menunjukkan tidak berpengaruh nyata terhadap jumlah daun kacang tanah. Terdapat kecenderungan bahwa perlakuan rhizobium menghasilkan jumlah daun lebih banyak jika dibandingkan dengan tanpa rhizobium ditunjukkan Tabel 3. Perlakuan rhizobium mampu meningkatkan jumlah daun tanaman kacang tanah meskipun tidak menunjukkan perbedaan yang nyata. Untuk memperoleh laju pertumbuhan maksimum, harus terdapat cukup banyak daun dalam tajuk untuk menyerap sebagian besar radiasi matahari yang jatuh ke atas tajuk tanaman. Menurut Jumini dan Hayati (2010) dengan semakin banyak jumlah daun dan semakin besar luas daun maka akan berpengaruh positif terhadap bobot kering tanaman.

Pada variabel jumlah cabang menunjukkan bahwa perlakuan pupuk granular organik tidak berpengaruh nyata terhadap variabel jumlah cabang umur 5 MST dan 7 MST. Pada perlakuan rhizobium menunjukkan tidak berpengaruh nyata terhadap jumlah cabang umur 5 MST namun berbeda nyata pada umur 7 MST. Perlakuan rhizobium ternyata menghasilkan jumlah cabang yang lebih banyak (5.56 batang) dan berbeda nyata jika dibandingkan dengan tanpa rhizobium ditunjukkan Tabel 4. Hal ini menunjukkan bahwa perlakuan rhizobium mampu meningkatkan jumlah cabang tanaman kacang tanah. Hal ini diduga rhizobium sebagai inokulan mampu meningkatkan ketersediaan nitrogen bagi tanaman, yang dapat mendukung peningkatan pertumbuhan dan hasil tanaman. Pendapat Saraswati dan Sumarno (2008), pemanfaatan rhizobium sebagai inokulan dapat meningkatkan ketersediaan nitrogen bagi tanaman, yang dapat mendukung peningkatan produktivitas tanaman kacang-kacangan. Selanjutnya menurut Setyawan et al., (2015), pemberian inokulum rhizobium $10 \mathrm{~g} / \mathrm{kg}$ benih dengan pupuk organik $1,000 \mathrm{~kg} \mathrm{ha}^{-1}$ memberikan hasil jumlah polong lebih tinggi dibandingkan dengan tanpa inokulum dan tanpa pupuk kandang. Arimurti (2000) menyatakan bahwa kemampuan rhizobium dalam menambat nitrogen dari udara dipengaruhi oleh besarnya bintil akar dan jumlah bintil akar. Sedangkan menurut Singh et al., (2008), menyatakan semakin tinggi jumlah bahan organic maka populasi mikroorganisme juga semakin tinggi.

Pada variabel bobot biji $\tan ^{-1}$ menunjukkan bahwa perlakuan pupuk granular organik berpengaruh nyata. Perlakuan pupuk granular organik $100 \mathrm{~g} \mathrm{tan}^{-1}$ dan $150 \mathrm{~g} \mathrm{tan}^{-}$ 1 menghasilkan bobot biji $\tan ^{-1}$ tertinggi masing-masing $9.38 \mathrm{~g}$ dan $9.32 \mathrm{~g}$ dan berbeda nyata dengan kontrol 
maupun pupuk granular organik $25 \mathrm{~g} \mathrm{tan}^{-1}$, meskipun tidak berbeda nyata dengan pupuk granular organik $50 \mathrm{~g} \mathrm{tan}^{-1}$ maupun $200 \mathrm{~g} \mathrm{tan}^{-1}$. Hal ini menunjukkan bahwa dosis granular organik $100 \mathrm{~g} \tan ^{-1}$ dan $150 \mathrm{~g} \mathrm{tan}^{-1}$ mampu meningkatkan bobot biji per tanaman kacang tanah. Peran pupuk organik ternyata mampu meningkatkan hasil panenan kacang tanah. Menurut Setyawan et al., (2015) pemberian inokulum rhizobium $10 \mathrm{~g} \mathrm{~kg}^{-1}$ benih dengan pupuk organik $1,000 \mathrm{~kg} \mathrm{ha}^{-1}$ dapat memberikan hasil indeks panen lebih tinggi. Pemberian pupuk organik dapat memperbaiki sifat fisik, tekstur dan struktur tanah, meningkatkan KTK tanah dan meningkatkan kapasitas menahan air. Pemberian inokulum rhizobium dengan pupuk organik dimaksudkan agar memberikan dampak positif untuk produksi kacang tanah dengan cara perbaikan sifat fisik, kimia dam biologi tanah. Sedangkan pemberian pupuk organik terutama ditujukan untuk perbaikan sifat fisik tanah seperti memperbaiki struktur tanah, meningkatkan kandungan lengas tanah, menyeimbangkan pori-pori tanah dan meningkatkan ketahanan terhadap erosi (Ma'shum,2008). Pada perlakuan rhizobium menunjukkan tidak berpengaruh nyata terhadap bobot biji $\tan ^{-1}$ ditunjukkan Tabel 5. Pemberian bahan organik dapat meningkatkan $\mathrm{pH}$ tanah, $\mathrm{P}$ tersedia, $\mathrm{N}$ total, KTK, Kdd dan menurunkan Al-dd, serapan P, fraksi Al dan Fe dalam tanah, sehingga dapat meningkatkan kandungan $\mathrm{P}$ tanaman, pada akhirnya hasil tanaman juga turut meningkat. Pupuk organik atau bahan organik memiliki fungsi kimia yang penting seperti: (1) penyediaan hara makro $(\mathrm{N}, \mathrm{P}, \mathrm{K}, \mathrm{Ca}$, $\mathrm{Mg}$, dan S) dan mikro seperti $\mathrm{Zn}, \mathrm{Cu}, \mathrm{Mo}, \mathrm{Co}, \mathrm{B}, \mathrm{Mn}$, dan $\mathrm{Fe}$, meskipun jumlahnya relatif sedikit. Penggunaan bahan organik dapat mencegah kahat unsur mikro pada tanah marginal atau tanah yang telah diusahakan secara intensif dengan pemupukan yang kurang seimbang; (2) meningkatkan kapasitas tukar kation (KTK) tanah; dan (3) dapat membentuk senyawa kompleks dengan ion logam yang meracuni tanaman seperti $\mathrm{Al}, \mathrm{Fe}$, dan Mn. (Balai Penelitian dan Pengembangan Pertanian, 2006).

\section{KESIMPULAN}

Perlakuan pupuk granular organik berpengaruh nyata terhadap bobot biji per tanaman dan perlakuan $100 \mathrm{~g} \mathrm{tan}^{-1}$ dan $150 \mathrm{~g} \mathrm{tan}^{-1}$ menghasilkan bobot biji $\tan ^{-1}$ tertinggi masing-masing $9.38 \mathrm{~g}$ dan $9.32 \mathrm{~g}$. Perlakuan rhizobium berpengaruh nyata terhadap tinggi tanaman dan jumlah cabang 6 MST. Perlakuan rhizobium menghasilkan tinggi tanaman tertinggi sebesar $36.11 \mathrm{~cm}$ dan jumlah cabang lebih banyak yaitu 5.56 batang. Tidak terdapat interaksi antara pupuk organik granular dengan rhizobium.

\section{DAFTAR PUSTAKA}

Adisarwanto, T. 2000. Meningkatkan Produksi Kacang Tanah di Lahan Sawah dan Lahan Kering. Penebar Swadaya. Malang.
Arimurti, S. Sutoyo, R. Winarsa. 2000. Isolasi dan karakterisasi rhizobia asal pertanaman kedelai di sekitar Jember. Jurnal Ilmu Dasar 1. (2):30-37.

Balai Penelitian dan Pengembangan Pertanian. 2006. Pupuk Organik dan Pupuk Hayati. Balai Besar Penelitian dan Pengembangan Sumberdaya Lahan Pertanian.

[Balitkabi] Balai Penelitian Tanaman Kacang-kacangan dan Umbi-umbian. 2008. Teknologi Produksi Kacang Tanah. Balai Penelitian Tanaman Kacang- kacangan dan Umbi-umbian. Malang (ID): Badan Penelitian dan Pengembangan Pertanian.

Bending, G.D., M.K. Turner, F. Rayns, M.C. Marx, M. Wood M. 2004. Microbial and biochemical soil quality indicators and their potential for differentiating areas under contrasting agricultural management regimes. Soil Biol Biochem. 36:17851792.

Direktorat Jendral Tanaman Pangan. 2012. Pengelolaan Produksi Tanaman Aneka Kacang dan Umbi Tahun 2012. Jakarta (ID): Direktorat Jendral Tanaman Pangan.

Sutedjo, M.M. 1995. Pupuk dan Cara Pemupukan Rineka Cipta, Jakarta.

Fitriana. D.A., T. Islami, Y. Sugito. 2015. Pengaruh dosis rhizobium serta macam pupuk kandang terhadap pertumbuhan dan hasil tanaman kacang tanah (Arachis hypogaea L.) varietas Kancil. Jurnal Produksi Tanaman. 3(7):547-555.

Jumini dan Rita Hayati. 2010. Kajian biokomplek trico$\mathrm{G}$ dan inokulasi rhizobium pada hasil tanaman kedelai (Glycine Max (L.) Merrill. Jurnal Floratek. 5(1):23-30.

Kari, Z., Z. Yuliar, Suhartono. 2000. Pengaruh pupuk Kalium (K) dan pupuk kandang terhadap pertumbuhan dan hasil kacang tanah. J Stigma. 8(2):123-126.

Leiwakabessy, F.M., A. Sutandi. 2004. Pupuk dan Pemupukan. Departemen Tanah. Fakultas Pertanian. Institut Pertanian Bogor. Bogor.

Marzuki, R. 2007. Bertanam Kacang Tanah. Jakarta (ID): Penebar Swadaya.

Ma'shum, M. 2008. Kesuburan Tanah dan Pemupukan. Fakultas Pertanian Universitas Mataram.

Mattjik, A.A., I.M. Sumertajaya. 2006. Perancangan Percobaan dengan Aplikasi SAS dan MINITAB. Bogor: IPB Press. 
Nuha, M.U., S. Fajriani, Arifin. 2014. Pengaruh aplikasi legin dan pupuk kompos terhadap tanaman kacang tanah (Arachis hypogaea L.) varietas Jerapah. Jurnal Produksi Tanaman. 3(1):1-6.

Padmanabha, I.G., I.M. Arthagama, I.N. Dibia. 2014. Pengaruh dosis pupuk organik dan anorganik terhadap hasil padi dan sifat kimia tanah pada Incepsol Kerambitan Tabanan. e-J. Agroekoteknologi Tropika. 3(1):41:50.

Saraswati, R., Sumarno. 2008. Pemanfaatan mikroba penyubur tanah sebagai komponen teknologi pertanian. Puslitbang. Jakarta. Jurnal Iptek Tanaman Pangan. 3(1):41-54.

Setyawan. F, M. Santoso, Sudiarso. 2015. Pengaruh aplikasi inokulus rhizobium dan pupuk organik terhadap pertumbuhan dan produksi tanaman kacang tanah (Arachis hypogaea L.). Jurnal Produksi Tanaman. 3(8):697-705.

Singh, B., R. Kaur, K. Singh. 2008. Characterization of Rhizobium Strain Isolated from the Roots of Trigonella foenumgraecum (fenugreek). African Journal of Biotechnology. 7(20): 36713676. 